\title{
Introduction: Modernism and the Origins of Caribbean Literature
}

Even if every date that permits us to separate any two periods is arbitrary, none is more suitable, in order to mark the beginning of the modern era, than the year 1492, the year Columbus crosses the Atlantic Ocean.

- Tzvetan Todorov, The Conquest of America

My mother said I'd be alone and when I cried (she said) I'd be Columbus of my ships and sail the gardens round the tears that fell into my hand.

-Edward Kamau Brathwaite, "Limbo"

Caribbean literature and culture are haunted by the presence of the "discoverer" and the historical moment he inaugurates. For if Columbus's "discovery" of the Americas and his initial encounter with the peoples of the New World have paradigmatic value in the European episteme because they usher in a brave new world, a world of modernity and modernist forms, as Tzvetan Todorov assumes in my first epigraph, these events also trigger a contrary effect on the people who are "discovered" and conquered. And while Eurocentric scholars have been eager to claim the conquest of the Americas as a radical and exemplary event that opens up the Old World's reconceptualization of its cultural traditions and temporality, and the constitution of the colonial other, Caribbean writers and scholars exhibit extreme anxiety and ambivalence toward the beginnings of modernity and modern- 
ism. ${ }^{1}$ This book is about this historical anxiety and ambivalence and the cultural and narrative forms Caribbean writers have developed both to represent and to resist the European narrative of history inaugurated by Columbus and the modern moment.

European admirers of modernity-most notably Todorov-may perceive Columbus as the quintessential figure of a modernity that breaks through the limits of tradition, leading us into what Bartolomé de Las Casas called "that time so new and like no other"; but for many Caribbean writers, the "discovery" was tantamount to what George Lamming would call "an unwelcome invasion of the American spine," a disastrous prelude to slavery and colonialism. ${ }^{2}$ Indeed, given the consequences of the European "modernization" of the New World, it appears almost impossible for Caribbean writers to accept Todorov's claim that "we are all the direct descendants of Columbus," and that it is with him that "our genealogy begins." 3 For the victims of slavery, colonialism, and indentured labor, it would be even more difficult to be comfortable in Jürgen Habermas's Hegelian conceptualization of the year 1500 as an "epochal threshold." 4 On the contrary, Caribbean writers, like their counterparts in the colonial and postcolonial worlds of Africa and Asia, are skeptical about any liberational claims for modernism and modernity because, as Simon During has noted in his excellent discussion of the relationship between modernity, colonization, and writing, the concept of the modern often derives its force from its Eurocentrism and its capacity to propel European expansion-"the West is modern, the modern is the West. By this logic, other societies can enter history, grasp the future, only at the price of their destruction." 5

Since entry into the European terrain of the modern has often demanded that the colonized peoples be denied their subjectivity, language, and history, it would be tempting to argue that Caribbean writers have sought new modes of expression and representation by rejecting modernity and by seeking or revalorizing ancestral sources from Africa and India. Indeed, some Caribbean writers and critics

1. For the "modernist implications" of the conquest of America, see Tzvetan Todorov, The Conquest of America, trans. Richard Howard (New York: Harper, 1984), pp. 1-5.

2. Here I have adopted Lamming's notion that Caribbean music has invaded the English spine. See The Pleasures of Exile (London: Allison and Busby, 1984), p. 77. Las Casas is quoted by Todorov, p. 5 .

3. Todorov, p. 5.

4. Jürgen Habermas, The Philosophical Discourse of Modernity: Twelve Lectures, trans. Frederick G. Lawrence (Cambridge: MIT Press, 1990), p. 5.

5. Simon During, "Waiting for the Post: Modernity, Colonization, and Writing," Ariel: A Review of International English Literature 20 (October 1989), 31. 
have explicitly rejected modernism, especially the "high" bourgeois variety that developed in Europe after the First World War, as a dangerous fallacy that represses the historicity of art and its function as a form of social critique. For example, Michael Thelwell, the eminent Jamaican novelist and critic, has argued that modernism has had a corrupting influence on twentieth-century Caribbean fiction; it functions as "the excuse and justification for a general retreat from [a] wide-ranging engagement with social and moral questions." 6

And yet there is a sense in which Caribbean writers cannot escape from modernism and its problematic issues, especially the questions of language, history, and the colonial subject which it raises. Generations of Caribbean writers and intellectuals have had to bear the burden of modern European history and its ideologies as that history was initiated by the "discovery" and then transformed, shaped, and even distorted by subsequent events and institutions such as the plantation system and the colonial condition. In this context, it was perhaps inevitable that the mother of the poetic speaker in Brathwaite's poem (which I use as my second epigraph) would sooner or later invoke the name of Columbus in her attempts to show her son ways of navigating a Caribbean world that Europe had tried to refashion in its own image. For whatever ideological positions Caribbean writers such as Brathwaite, Lamming, and others have taken on the meaning of the "discovery," they are all forced to redefine themselves in relation to this moment. They realize that the time inaugurated by the European colonization of the Americas sets up a modern tradition of representation which still haunts the Caribbean.

Thus the history initiated by the conquest and invention of America has become what George Lamming once called "a sad and hopeful epic"; it destroys aboriginal cultural forms, but it also enables the Caribbean discourse of resistance and cultural transformation in which old African cultures become "modernized" by African slaves as they struggle to survive in a hostile terrain invaded by "human heroes and victims of an imagination shot through with gold." 7 My basic premise, then, is that Caribbean writers cannot adopt the history and culture of European modernism, especially as defined by the colonizing structures, but neither can they escape from it because it has overdetermined Caribbean cultures in many ways. Moreover, for peoples of

6. Michael Thelwell, "Modernist Fallacies and the Responsibility of the Black Writer," in Duties, Pleasures, and Conflicts: Essays in Struggle (Amherst: University of Massachusetts Press, 1987), p. 221.

7. Lamming, The Pleasures of Exile, p. 17. 
African and Asian descent, the central categories of European modernity-history, national language, subjectivity-have value only when they are fertilized by figures of the "other" imagination which colonialism has sought to repress. In this sense, Caribbean modernism is highly revisionary. As Wilson Harris, possibly the most self-conscious Caribbean modernist, has argued, modern "implies an ongoing and unceasing re-visionary and innovative strategy that has its roots in the deepest layers of that past that still address us."

This book is primarily concerned with this revisionary strategy in West Indian literature, a strategy necessitated by Caribbean writers' attempts to rescue their cultures from what Michel de Certeau, writing on the conquest of the New World, has called the discourse of European power which uses the New World "as if it were a blank, 'savage' page on which Western desire will be written." 9 Because the Africa diaspora was constituted, as Paul Gilroy says, in "a milieu of dispossession," modernity and modernism in the Caribbean pose a set of questions different from that raised in an Anglo-American context. ${ }^{10}$ Does the Caribbean writer, driven by what Edouard Glissant calls "the daring adventure of modernity," reject tradition and literary continuity in order to "give meaning to the reality of [the] environment"? 11 If this is the case, what is the status of borrowed European (and hence colonial) literary conventions and of African traditions brought to the Caribbean by slaves and sustained by the peasantry? If Caribbean literature is both haunted and sustained by modernism and modernity, as I argue in this introduction, what exactly are the ideology and form of Caribbean modernism and how do they appropriate or reject the hegemonic European idea of the modern as an affect of Western reason and history?

\section{The Irruption into Modernity}

In order to contextualize Caribbean modernism and its cultural politics, we need to conceive it as opposed to, though not necessarily

8. Stephen Slemon, "Interview with Wilson Harris," Ariel: A Review of International English Literature 19 (July 1988), 48.

9. Michel de Certeau, The Writing of History, trans. Tom Conley (New York: Columbia University Press, 1988), p. xxv.

10. Paul Gilroy, There Ain't No Black in the Union Jack: The Cultural Politics of Race and Nation (London: Hutchinson, 1987), p. 219.

11. Edouard Glissant, Caribbean Discourse: Selected Essays, trans. J. Michael Dash (Charlottesville: University Press of Virginia, 1989), p. 146. 
independent of, European notions of modernism. For there is a sense in which much hostility toward modernist Caribbean texts arises from the tendency to limit definitions of modernism to the twentieth century and to the high modernist aesthetic articulated by Anglo-American writers such as Ezra Pound, T. S. Eliot, and James Joyce. It is this rather limited conceptualization of modernism which has compelled Thelwell to argue, wrongly in my view, that modernist forms lead to the writer's abandonment of "history and cultural reality."12 Thelwell's definition of modernism is further limited by his negation of the historical conditions that make Caribbean and Afro-American literature possible: in arguing that modernism is diffused "into the cultures of the African world, Black America, and the Caribbean . . . as a result of myth and institutions," he refuses to countenance the historical necessity of what one may call a Third World modernism distinct from the prototypical European form which, in Houston Baker's words, "is exclusively Western, preeminently bourgeois, and optically white."13

The long history of colonialism in the Caribbean, and the construction of its cultural landscape under European hegemony, have generated what Glissant aptly calls the region's irruption into modernity as a violent departure from the colonial tradition. Two themes, then, will help us conceptualize this irruption and the narrative and discursive techniques it generates: first, I argue that Caribbean modernism has evolved out of an anxiety toward the colonizing structure in general and its history, language and ideology in particular; second, I examine how this modernism, which is closely related to the process of creolization, develops as a narrative strategy and counter-discourse away from outmoded and conventional modes of representation associated with colonial domination and colonizing cultural structures.

Nowhere is the essential modernity of Caribbean literature as apparent as in the writers' anxiety toward their history; as John Hearne noted in his introduction to the 1976 Caribbean Arts Festival (Carifesta) anthology, "History is the angel with whom all we Caribbean Jacobs have to wrestle, sooner or later, if we hope for a blessing."14 While European modernists would posit history as a nightmare from which the aesthetic imperative was going to rescue the artist, Caribbean literature has often been haunted by the projection of the Carib-

12. Thelwell, p. 221.

13. Thelwell, p. 236; Houston A. Baker, Jr., Modernism and the Harlem Renaissance (Chicago: University of Chicago Press, 1987), p. 6.

14. John Heame, "Introduction," Carifesta Forum: An Anthology of 20 Caribbean Voices, ed. John Hearne (Kingston: Institute of Jamaica, 1976), p. vii. 
bean colonial subject as either an ahistorical figure of European desire or simply a victim of the history of conquest and enslavement. Caribbean writers simultaneously represent colonial history as a nightmare and affirm the power of historicity in the slave community. This double gesture is not difficult to explain. The African slaves in the New World were denied their history as a precondition for enslavement; to claim subjectivity, they had to struggle for their essential historicity. In the plantation economy, as the Jamaican sociologist Orlando Patterson has observed, slaves were represented as socially dead, without cultural authority, excommunicated from their history, and isolated from their genealogy. The slave, says Patterson, was formally "isolated from his social relations with those who lived" and was "culturally isolated from the social heritage of his ancestors":

He had a past, to be sure. But a past is not a heritage. Everything has a history, including sticks and stones. Slaves differed from other human beings in that they were not allowed freely to integrate the experience of their ancestors into their lives, to inform their understanding of social reality with the inherited meanings of their natural forebears, or to anchor the living present in any conscious community of memory. That they reached back for the past, as they reached out for the related living, there can be no doubt. Unlike other persons, doing so meant struggling with and penetrating the iron curtain of the master, his community, his laws, his policemen or patrollers, and his heritage. ${ }^{15}$

In spite of the repression of their history during the "middle passage," slaves sustained their culture by memories of the past, of severed kinship with Africa, and by the desire for an epistemology that preceded slavery. However, the point that needs to be foregrounded in Patterson's theory of slavery as social death, and indeed of Caribbean culture as a whole, is the extent to which slaves were denied a consciousness of their historicity. Slaves were not free to claim a historical consciousness independent of the slave master, nor were they allowed to anchor their lives around value systems imported from Africa; as a result, historicity (as distinct from history) was something to be struggled for against the machinery of the plantation and the colonial state. Since colonial modernity denied the Caribbean an "other" history-a version of events distinct from the conventional European narrative in which the islands exist solely as a project of the

15. Orlando Patterson, Slavery and Social Death: A Comparative Study (Cambridge: Harvard University Press, 1982), p. 5. 
conqueror's expansionism-West Indian writing would come to function as a forced entry (into history) through the iron curtain of colonial culture. This forced entry, however, would not be merely an attempt to reclaim a repressed past through the imaginary act; it would also function as an attempt to invent an emancipatory Caribbean narrative of history. As Roberto Marquez has observed, the reconstitution of the Caribbean past, which also demands a critical examination of the past, establishes "the prehistory of the present-active, unreconciled, unpropitiated, contradictory, continuing or permanent presence-and the proper ground for establishing the entelechy, cultural and national, of a Caribbean ethos."16

A Caribbean narrative of history is further necessitated by the colonized writers' need to contest the meaning and method of colonial historiography, especially its totalizing gestures. Glissant has observed that in the historiography of colonial modernism-in which history is a "highly functional fantasy of the West" - the process of historicization involves both a strategic dislocation of the colonized and the ideological imposition of "a single History, and therefore of power."17 Furthermore, colonial history, whose system of signs is an integral part of the narrative of domination and control, attempts, in the words of J. Michael Dash, to "fix reality in terms of a rigid, hierarchical discourse":

In order to keep the unintelligible realm of historical diversity at bay, History as system attempts to systematize the world through ethnocultural hierarchy and chronological progression. Consequently, a predictable narrative is established, with a beginning, middle, and end. History then becomes, because of this almost theological trinitarian structure, providential fable or salvational myth. ... History ultimately emerges as a fantasy peculiar to the Western imagination in its pursuit of a discourse that legitimizes its power and condemns other cultures to the periphery. ${ }^{18}$

In their quest for a decolonized Caribbean discourse, however, many West Indian writers consider what Dash calls a trinitarian structure to be the Achilles' heel of colonial historiography: in assuming that there is only one history, Western history, colonial discourse is

16. Roberto Marquez, "Nationalism, Nation, and Ideology: Trends in the Emergence of a Caribbean Literature," in The Modern Caribbean, ed. Franklin W. Knight and Colin A. Palmer (Chapel Hill: University of North Carolina Press, 1989), p. 324.

17. Glissant, p. 93.

18. J. Michael Dash, "Introduction," in Glissant, Caribbean Discourse, p. xxix. 
blind to the fragmentation and diversity that will return to haunt it. Indeed, the very historical moments in which European history appears triumphant because it has achieved, through the conquest of the other, the Hegelian dream of modernity as the manifestation of the Absolute Spirit, contain within them the strains that rupture the totality of the colonizing structure. These strains attract Caribbean writers and intellectuals because they seem to provide an opportunity for subverting colonial discourse at its foundations. Thus Lamming is attracted to Caribbean history in the late sixteenth and early seventeenth centuries because "it's a period which contains all the stresses that go with an emerging nationalism." 19 However, in considering this period in which the European powers seemed to have consolidated their control over the islands, the Caribbean novelist-writing in the period of decolonization-is not seduced by the imperial ideas that dominated the sixteenth and seventeenth centuries, but by their corollary-nationalism and national identity. Similarly, while the history of Martinique has been written in the colonial text as the continuity of French history - the temporary abolition of slavery (1794), emancipation (1848), and departmentalization (1946) are all presented as consequences of central events in French history-Glissant seeks to expose the "real discontinuity beneath the apparent continuity of our history." 20 In both cases, the central paradigms of colonial historicitysystematization, chronology, and closure-are heavily contested.

Some Caribbean writers have, of course, suggested that to escape the prisonhouse of colonial history, the writer must expunge history from the imaginary text altogether. The most important proponent of this view, which is akin to the high modernist desire to transcend history as a precondition for liberating the self from its alienating structures, is Derek Walcott, the St. Lucia poet. In "The Muse of History," Walcott argues that the great poets of the New World reject history because it is "fiction, subject to a fitful muse, memory"; history chains writers to the past and thus forecloses the language of liberation; a literature that "serves" historical truth "yellows into polemic or evaporates in pathos." 21 For Walcott, "the truly tough aesthetic of the New World neither explains nor forgives history. It refuses to recognize it as a creative or culpable force. This shame and awe of history possess poets of the Third World who think of language as enslave-

19. Quoted in George Kent, "Caribbean Novelist," Black World 22 (March 1973), 14.

20. Glissant, p. 91.

21. Derek Walcott, "The Muse of History," in Hearne, Carifesta Forum, p. 112. 
ment and who, in a rage for identity, respect only incoherence or nostalgia."22

Does Walcott, then, see the poetic act as truly liberating only if it secures the writing self a niche in what Linda Hutcheon calls, in another context, "the hermetic ahistoric formalism and aestheticism" of high modernism?23 Or is Glissant closer to the truth when he suggests that what Walcott rejects is not the validity of historicity but the valorization of inherited categories of history and an "affirmation of the urgency of a revaluation of the conventions of analytical thought?"24 Clearly, some of Walcott's best poetry (the "Schooner's Flight," for example) is generated by the tension between language and the "burden of history" which the poet consigns to others in his poetic theory. In the circumstances, the poet seems to become enmeshed in history the more he tries to escape from it.

Glissant's suggestion that what is at issue in Walcott's devalorization of history is the desire to deconstruct the analytic conventions of that history is pertinent to the Caribbean's quest for its own modes of representation because, as we will see in several chapters in this book, the march of European modernist history in the New World is often posited as the triumph of reason and the systematization of time and space. In the circumstances, Walcott's refusal to recognize history as a creative force is really a negation of a European model of history anchored on notions of progress and temporal closure. In contrast, a decolonized discourse seeks forms of representing a history of displacement and reversal and valorizes strategies of inscribing and evoking what Maximilien Laroche, the Haitian writer, has called "the otherness of identity" found in the "theater of our contradictions." $25 \mathrm{My}$ other intention in this study is to argue that Caribbean modernism has developed to articulate the identities constituted by such historical contradictions.

In arguing for a Caribbean modernism that contests colonial history,

22. Walcott, "The Muse of History," p. 112.

23. The phrase is used by Linda Hutcheon in A Poetics of Postmodernism: History, Theory, Fiction (New York: Routledge, 1988), p. 88. As I try to show in subsequent chapters, the kind of problematization of history which Hutcheon attributes to postmodernism-in reaction against the "modernist period" - has been one of the defining attributes of what I refer to as Caribbean modernism.

24. Glissant, p. 65.

25. See Maximilien Laroche's contribution to the discussion in Process of Unity in Caribbean Society, ed. Ileana Rodriguez and Marc Zimmerman (Minneapolis: Institute for the Study of Ideologies, 1983), p. 111; and Patrick Bellegarde-Smith, In the Shadow of Powers: Dantès Bellegarde in Haitian Social Thought (Atlantic Highlands, N.J.: Humanities Press, 1985), pp. 181-82. 


\section{INTRODUCTION}

I am well aware that this modernity and its forms may still be imprisoned in the very European paradigms it seeks to negate. The risk of formulating a theory of Caribbean modernism which is haunted by the shadows of the colonizing structures is, of course, enormous: we cannot tell when a counter-discourse finally breaks away from the discourse it critiques, nor does my placement of Caribbean narratives in the gap between a colonial and a decolonized narrative, between Europe and Africa, provide much certainty or ideological consolation. But this risk is worth taking for two reasons: First, any turn to Africa or India for an ideological rescue plan does not seem to mitigate the anxieties of European history discussed above. At best, as Edward Brathwaite's trilogy, The Arrivants, has shown so well, Africa is only a prelude to the adventure of Caribbean modernity. The Caribbean writer returns to Africa not in search of a cure for alienation and displacement, nor to overcome the psychological gap denoted by the middle passage, but to evolve a genealogy of his or her origins; this genealogy leads to the development of a radical consciousness of history, but it also actualizes the trauma of imperialism which has overrun the ancestors.

My contention, then, is that Caribbean writing is not so much motivated by the desire to recover an "original" model-the unhistoried African body that predates slavery and colonialism-as by the need to inscribe Caribbean selves and voices within an economy of representation whose institutional and symbolic structures have been established since the "discovery." If we accept Glissant's basic argument that the essential modernity of New World writers is the desire to write a new history of the region, Africa does not proffer an ideal history to counter the disorder of colonialism, except at the expense of mystification. The slave trade, says Glissant, is the journey "that has fixed in us the unceasing tug of Africa against which we must paradoxically struggle today in order to take root in our rightful land. The motherland is also for us the inaccessible land." 26

Glissant's double gesture-he affirms the necessity of Africa in the Caribbean consciousness even as he asserts its remoteness-points to the second reason why I risk adopting modernism as a conceptual category: even when it is haunted by its imposed metropolitan identity and its desired ancestral image, the Caribbean imagination is sustained by the tug of both Europe and Africa. This tug, which can be as

26. Glissant, pp. 160-61. 
enriching and ennobling as it can be depreciative and enslaving, has often functioned as the enabling condition of Caribbean social thought and cultural production at crucial historical junctures. For example, in nineteenth-century Haiti, as Patrick Bellegarde-Smith notes in an excellent examination of Haitian social thought, the newly independent ruling class could not countenance the value of the African-derived language and culture of the peasantry; indeed, this class could not countenance the possibility of a Haitian national culture independent of France. The men who had fought and defeated French enslavement held a firm belief that the Americas constituted a new social practice that, nevertheless, perpetuated the old European spirit. BellegardeSmith notes that in both Haiti and the Hispanic islands that became independent at the end of the nineteenth century, the predominant social theory was that the Americas would improve upon Europe, with which they shared a "common culture"; at the time of independence, "there was seemingly no alternative to modernization seen as westernization." 27

It was in reaction to this assumed continuity between Europe and the Caribbean that a later generation of Caribbean writers such as Jean Price Mars and Aimé Césaire sought to revalorize Africa in the Caribbean imagination. As Césaire told Charles Rowell, "If Senghor and I spoke of Negritude, it was because we were in a century of exacerbated Eurocentrism, a fantastic ethnocentrism, that enjoyed a guiltless conscience." 28 In any case, irrespective of where they sought their identity, Caribbean writers could not escape the anxieties generated by their historical conditions-they were colonial subjects and they had to write for or against colonial modernism. Whether they were Eurocentric or Afrocentric, these writers lived in a colonial condition that was, by its very definition, an extreme state of anxiety.

But before I trace these anxieties, especially as they are manifested in language and subjectivity, I want to emphasize my basic contention

27. Bellegarde-Smith, p. 181. The strategic position of modernism and literary production in the New World has been discussed by Roberto Gonzalez Echevarria in numerous essays. His observation that "Latin America as a concept and as a political reality was created at the outset of modernity, that is to say, at the historical juncture that also brought into being the question of cultural existence, both as a question and as a conceptual need" applies equally to the Caribbean basin. See The Voice of the Masters: Writing and Authority in Modern Latin American Literature (Austin: University of Texas Press, 1985), p. 11. Gonzalez Echevarria discusses the conjunction of modernity and historicity in "Literature of the Hispanic Caribbean," Latin American Literary Review 8 (Spring-Summer, 1980), 4-5.

28. Charles Rowell, "It Is through Poetry That One Copes with Solitude: An Interview with Aimé Césaire," Callaloo 12 (Winter 1989), 55. 


\section{INTRODUCTION}

that the colonial anxiety does not necessarily disable the colonized writer; rather, it enables a narrative of liberation in the colonizer's language. The colonized writer who suffers a crisis of identity because he or she cannot feel at home in imposed colonial spaces is inevitably driven to subvert the given form and language. Also, as Houston A. Baker has observed in his seminal study of Afro-American modernism, this kind of anxiety can indeed open up radical discursive possibilities:

Modernist "anxiety" in Afro-American culture does not stem from a fear of replicating outmoded forms or of giving way to bourgeoisie formalisms. Instead, the anxiety of modemist influence is produced, in the first instance, by the black spokesperson's necessary task of employing audible extant forms in ways that move clearly up, masterfully and resoundingly away from slavery. ${ }^{29}$

For Caribbean peoples, however, "re-sounding" away from slavery and colonization demanded a certain reconceptualization of the colonial language and its ideological terrain. The result was a creole culture that according to Patrick Taylor "enabled peoples disrupted by the slave trade to recreate themselves, to distance themselves from those who tried to control their minds." 30 Modern Caribbean writers are framed by this creole culture on one side and the colonial episteme on the other side.

\section{Modernism: Creolization and Maroonage}

In what space, wonders Glissant in a crucial moment in Caribbean Discourse, is a poetics of Antillean writing going to be articulated? Since the European metropolitan space is too compromised (it carries all the baggage of enslavement and colonization) and the African terrain is inaccessible, Glissant, like many of his contemporaries, has sought to position his art and discourse in a "twilight" consciousness between the ancestral sources and the colonizing structures. Because it is not fixed in any epistemic position, or rather does not have to see the appropriation of one paradigmatic value (for example the Euro-

29. Baker, p. 101.

30. Patrick Taylor, The Narrative of Liberation: Perspectives on Afro-Caribbean Literature, Popular Culture, and Politics (Ithaca: Cornell University Press, 1989), pp. 228-29. 
pean language) as the negation of another value (such as African folklore or religion), the twilight consciousness offers limitless ideological possibilities; from a linguistic perspective, the twilight zone is not indebted to old social and cultural models, conventions, or idioms. Most important, as Dash observes in relation to Glissant's poetics, the writer who operates in the space between cultural traditions draws inventive energies from "creative schizophrenia": speaking an androgynous idiom, this writer does not have to choose between self and community, between a private discourse and a national language, or even between the subjective experience and historical traditions. ${ }^{31}$ On the contrary, this kind of writer is able to move from one value to the other and to break the binary oppositions that sustain such values as mutually exclusive entities. As Wilson Harris notes, the twilight situation, which "half-remembers, half-forgets," enables "the language of consciousness" to "rediscover and reinform itself in the face of accretions of accent and privileges, the burden of 'sacred' usage or onesidedness." 32

In the circumstances, the Caribbean writer cannot be the slave of a canonical tradition that burdens us with its "sacred" claims; on the other hand, unlike their European counterparts, Caribbean writers have no need to retreat from their social environment or cultural traditions. The capacity to reject epistemological fixations turns the language of Caribbean literature into what Walcott calls an instrument of deliverance from servitude; existing in the twilight zone of colonial culture, blacks in the New World were forced to forge "a language that went beyond mimicry, a dialectic which had the force of revelation as it invented names for things, one which finally settled on its own mode of inflection, and which began to create an oral culture of chants, jokes, folksongs and fables." 33 Moreover, enslaved blacks could lay claim to the New World through a creative use of the social spaces in which they were imprisoned, thereby reverting their terrible irruption into the plantation system into a fundamental value to which all other values in the slave community could refer. In other words, the slaves' journey from the Old World to the New World would open up the African imagination to other temporal and spatial possibilities, while

31. Dash, "Introduction," p. xxvi.

32. Wilson Harris, Tradition, the Writer, and Society: Critical Essays (London: New Beacon Publications, 1973), p. 64. See also Derek Walcott's literary manifesto, "What the Twilight Said: An Overture," in Dream on Monkey Mountain and Other Plays (New York: Farrar, 1970), pp. 340.

33. Walcott, "What the Twilight Said," p. 17. 
at the same time demanding a new idiom and form. The "modernization" of African cultures in the Caribbean (what has come to be known as creolization) is the process by which exiled Africans set out to develop modernist ways of seeing, knowing, and representing their dislocated culture-aware, no doubt, of its aboriginal sources, but motivated by the need to account for new social and historical forms.

The most dramatic metaphor for this process of cultural transformation is the limbo dance. Edward Brathwaite, who sees the limbo dance as a metacode for New World writing in general, speculates that the dance evolved on the slave ships in the middle passage as a therapy for the cramped conditions in the holds: it was a creative way of using limited dancing space. ${ }^{34}$ For Wilson Harris, the limbo dance is an appropriate metaphor for the middle passage, which serves as a gateway between Africa and the Caribbean and as a form of cultural dislocation, a figure of the doubleness that infuses Caribbean writing. Thus, although the middle passage represents the temporal moment when the slaves are dislocated from Africa, it is also a challenge to them to reassemble their cultural fragments, fuse their multiple ethnic identities, and appropriate imprisoned social spaces; the "dislocation of interior space serves as a corrective to a uniform cloak or documentary stasis of imperialism." 35 Indeed, in most Caribbean writing, dislocation and its imaginary correctives go hand in hand; however, they are both functions of the stasis of imperialism which they seek to subvert.

Being in "limbo" does have its anxieties, but what makes this cultural space attractive to Caribbean writers is its generation of ironic forms that undermine the authority of imperialist discourse and its dominant figures. Readers of Edward Brathwaite's poem "Limbo" can fail to recognize its ironic undercurrent only at their own peril. For one thing, the authority of the mother who throws her son ashore and asks him to navigate his ship in tears like Columbus in reverse is called into question by her state of mind-she is described as the "cracked mother," mad in the sense that she is unaware of the absurdity of the Columbian model she holds up for her son. ${ }^{36}$ After all, if Columbus was such a good navigator, why did he end up in the wrong place?

34. See Edward Brathwaite, "Limbo," in The Arrivants: A New World Trilogy (London: Oxford University Press, 1973), pp. 179-205. Brathwaite provides an important historical notation on the limbo dance in his glossary to this collection of poems (p. 274).

35. Wilson Harris, Explorations: A Selection of Tales and Articles 1966-1981, ed. Hena MaesJelinek (Geding Sovej, Denmark: Dangaroo Press, 1981), p. 28.

36. Brathwaite, "Limbo," p. 170. All further references to thepoemare included in the text. 
Surely the European model is one that needs to be questioned and made ironic at every juncture.

The ironic nature of the poem becomes even more apparent when we recognize the contradictory terms Brathwaite uses to re-present the inaugural moments of Caribbean modernity. On the sea of his tears the boy sees three nuns who later turn out to be emblems of Columbus's ships_-"Santa Marias with black silk sails" (p. 180)—and slowly he realizes that to replay the journey of the discovery, that is, to adopt European forms to represent Caribbean conditions, he must at the same time negate his selfhood and become an agent of domination and repression. And yet, what choice does the subject have? His predicament is made worse by the realization that an ideal history of the Caribbean is ultimately inaccessible except as fantasy: "We wanted land as it should be," says the poetic speaker, "hard and firm; the trees deep-rooted / the orchards well spaced / churches quiet and heavy as stone" (p. 183). The reality, however, is a reversal of such expectations, for the islands have lost their balance, "suddenly fallen and drowned" (p. 184).

Thus a modernist anxiety generates irony in this poem: the poetic speaker, now reduced to a function of the colonizing structure, does not even know how to navigate his own world: "how will new maps be drafted? / Who will suggest a new tentative frontier? / How will the sky dawn now?" (p. 184). Such questions about maps and boundaries are symptoms of the "inner dichotomy" (what Marshall Berman, in a general history of modernism, calls the "inner sense of living in two worlds simultaneously") through which the categories of colonial modernism and modernity emerge. ${ }^{37}$ The most obvious manifestation of this dichotomy is the fact that the poetic speaker seeks to map a Caribbean landscape but he speaks a European language already loaded with Eurocentric figures.

Another source of anxiety for Caribbean writers is the uneasy convergence of modernism and colonialism, especially in those cases where colonized writers have aligned themselves with the European literary avant-garde. For it was not uncommon, especially in the colonial period, for colonized writers to use forms and figures borrowed

37. Marshall Berman, All That Is Solid Melts into Air: The Experience of Modernity (New York: Penguin, 1988), p. 17; Berman's ideas on modernism, modernity, and modernization are discussed by Perry Anderson in "Modernity and Revolution" in Marxism and the Interpretation of Culture, ed. Cary Nelson and Lawrence Grossberg (Urbana: University of Illinois Press, 1988), pp. 317-34. 
from European modernism as a point of entry into certain aspects of Western culture, or to "naturalize" European languages to Caribbean cultures. This process of naturalizing the dominant language has its parallels in doctrines of modernization in the region. For example, in his Discourse on Colonialism, Aimé Césaire is agitated by any notion that he is an "enemy of Europe" or the mere thought that he ever urged colonized peoples to return to "the ante-European past." On the contrary, the colonized peoples are the vanguard of the modernizing project; "it is the African who is asking for ports and roads, and colonialist Europe which is niggardly on this score . . . it is the colonized man who wants to move forward, and the colonizer who holds things back." 38

Inevitably, there is a more important linguistic twist to this claim: Césaire works within the French language, but as he tells René Depestre in a 1967 interview, he has always striven to create a new language, a language "capable of communicating the African heritage." The old French language-which not only has supported an injust colonial praxis but has also become "burdensome, overused" can be renewed by "an Antillean French, a black French that, while still being French, had a black character." 39 In other words, the French language could be "creolized" and thus forced to account for a different, Caribbean-centered experience. For many Caribbean writers and intellectuals, creolization has come to represent a unique kind of Caribbean modernism, one that resists the colonizing structures through the diversion of the colonial language and still manages to reconcile the values of European literacy with the long-repressed traditions of African orality. ${ }^{40}$

The notion of creolization as an essential component of Caribbean modernism has both a political and theoretical function. On one hand, the political function of creolization can be found in the writings and activities of the founders of Cuba and Haiti, the first Caribbean countries to become independent, who sought to harmonize the racial and caste differences brought about by the plantation system by promoting creolization as a process of refashioning the Old World into a new national culture. In the context of the Ten Years' War of Cuban independence (1868-78), for example, José Martí would posit cultural syncretism as the fundamental code for explaining Caribbean culture; the

38. Aimé Césaire, Discourse on Colonialism, trans. Joan Pinkham (New York: Monthly Review Press, 1972), p. 25.

39. Césaire, Discourse, pp. 66, 67.

40. See Glissant, pp. 122-28. 
intermingling of cultural forms was a harnessing of "the elements composing the islands." 41 Earlier, in a newly independent Haiti, Toussaint L'Ouverture seems to have foreseen linguistic creolization as a gesture toward what Roberto Marquez calls "the control of the international language" in the service of the state:

And this is because the new state has destroyed the economic substratum on which the prior state had depended; it has restructured the plantation relationship, and it has severed much of its continuity with the past. The revolution meant a beginning and a new basis, as well as an end to the old bases. It was a beginning in which all elements, relations and norms in the realm of culture, aesthetics and linguistics would be recreated and resynthesized in function of the state's emergent political economy. ${ }^{42}$

On the other hand, creolization-in its theoretical and more contemporary strand-is appropriated as a figure of modernism because it opposes the synchronic vision of colonial historiography with the diachronic narrative of a cross-cultural imagination. ${ }^{43}$ The colonial vision is presented as essentially synchronic because it insists on the fixation of the identity of the dominated; the narrative of creolization, on the other hand, insists on the transmutation and transformation of the colonial subject-and its culture-toward a realm of freedom. According to Edward Brathwaite, who has written more on creolization than any other Caribbean historian, the matrix of creolism signalizes both the adaptation of ancestral forms to the Caribbean environment and the quest for alternatives to European cultural traditions. Creolism thus suggests "subtle and multiform orientations from or towards ancestral origins": "In this way, Caribbean culture can be seen in terms of a dialectic of development taking place within a seamless guise or continuum of space and time; a model which allows for blood flow, fluctuations, the half-look, the look both/several ways; which allows for and contains the ambiguous, and rounds the sharp edges off the dichotomy." 44

Brathwaite's recognition that creolization must allow for fluctua-

41. Quoted in Marquez, "Nationalism, Nation, and Ideology," p. 298.

42. Roberto Marquez, contribution to the discussion in Rodriquez and Zimmerman, Process of Unity in Caribbean Society, p. 75.

43. I'm using diachrony here-in the sense popularized by Edward W. Said-as the process by which narrative destabilizes a hegemonic system of meanings and hence functions as an agent of change and transformation. See Said, Orientalism (New York: Vintage, 1979), p. 240.

44. Edward Brathwaite, "Caribbean Man in Time and Space," in Hearne, Carifesta Forum, p. 204 . 
tions has important consequences for my discussion. His eclectic description of creolism allows him to counter the orthodoxy of state doctrines of creolization which sometimes create the illusion that the relationship of all the parts that make the whole is egalitarian. He also recognizes that the kind of syncretism which some Caribbean writers seem to find in creolization portends a will to cultural synthesis which sometimes obscures the racial, ethnic, and caste tensions that often militate against the formation of a unified national or Pan-Caribbean culture. For Brathwaite, then, the central problem of Caribbean culture is not how to account for its totality but rather how to express "the extraordinary complexity of what we call creolization," how "to study the fragments/whole." 45 In other words, modern Caribbean writing will not be predicated on a theory of a unified organic self, or the nonproblematic relationship among this self, its world, and language. For if we were to succumb to a sensual and essential theory of language and writing in which literature valorizes the "possibility of the integration of feeling/knowledge, rather than the split between the abstract and the emotional," as Barbara Christian has recently argued, then we would be sustaining one of the greatest illusions of colonialist discourse, its repression of differences, its futile struggle to represent the colonized as a junior and inferior partner in a Pax Britannica or other colonial mythology. ${ }^{46}$ It is important to note that although it sustains a social and economic structure that draws from even the dubious wells of biological divisions, the colonial enterprise has cultivated a colonialist discourse (defined most aptly by Peter Hulme as "an ensemble of linguistically-based practices unified by their common deployment in their management of colonial relationships ${ }^{\prime \prime 7}$ ) as a key instrument of its cultural hegemony.

An integrated discourse of self is surely the ultimate or possibly utopian desire of Caribbean writing, but it can only be reached after the negotiation of a historically engendered split between the self and its world, between this self and the language it uses. The despair of Caribbean modernist literature-and also the condition that makes it possible-is expressed by the Haitian poet Léon Laleau in his 1931 "Trahison" (Betrayal):

45. Brathwaite, "Caribbean Man," p. 199.

46. Barbara Christian, "The Race for Theory," Cultural Critique 6 (Spring 1987), 55-56.

47. Peter Hulme, Colonial Encounters: Europe and the Native Caribbean 1492-1797 (London and New York: Methuen, 1986), p. 2. 
This haunted heart that doesn't fit

My language or the clothes I wear

Chafes within the grip of

Borrowed feelings, European ways. ${ }^{48}$

Laleau's dilemma-how to negotiate the chasm between a colonial language and an African-derived culture-has been echoed by many other Caribbean writers; in its most dramatic form, the problem of selfrepresentation in an alienating language is exemplified by the suicide of the Haitian poet Edmond Laforest, who tied a Larousse dictionary around his neck before he drowned himself to protest the hegemony of the colonial library. 49

Although the political desire to unify the fragments that mark the Caribbean landscape is urgent and necessary, the modern drama of creolization is marked by linguistic conflicts and cultural indentureship. So long as creolization is overdetermined by colonialism and neocolonialism, it still carries the Manichaeanism of the colonial situation and the violence it engenders. The relationship between the literate (European) and the oral (Caribbean) cultures, between the colonizer and the colonized, is, as Césaire succinctly notes, devoid of human contact; this relationship is "nothing but the relationship of domination and submission which turns the colonising man into a warder or a whip, and the indigenous man into an instrument of production." 50 Since the colonial language is an instrument of domination and submission, how is it going to be adapted to the narrative and discourse of liberation? Interestingly, the linguistic crisis the Caribbean writer faces at this juncture is similar to that which confronted European high modernist poets at about the same time Laleau, Laforest, and Césaire began to write: how can literary language face the pressures of its objective conditions and yet liberate itself from them?51 My basic premise, then, is that the history of Caribbean literature can be written as the evolution of a discourse striving to establish its identity within the parameters defined by the European language and

48. Léon Laleau, "Betrayal," in The Negritude Poets, ed. Conroy Kennedy (New York: Thunder's Mouth Press, 1975), p. 15.

49. The episode is reported by Henry L. Gates, Jr., "Writing 'Race' and the Difference It Makes," Critical Inquiry 12 (Autumn 1985), 13.

50. Césaire, Discourse, p. 27.

51. For the pressures that generated the language of European high modernism, see Alan Wilde, Horizons of Assent: Modernism, Postmodernism, and the Ironic Imagination (Baltimore: Johns Hopkins University Press, 1981), p. 99; and Theodor Adorno, Aesthetic Theory, trans. C. Lenhardt, ed. Gretel Adorno and Rolf Tiedemann (London: Routledge, 1984), p. 49. 


\section{INTRODUCTION}

culture which it strives to disperse. My argument here is that Caribbean writers, in response to their historical marginalization, have evolved a discourse of alterity which is predicated on a deliberate act of self-displacement from the hegemonic culture and its central tenets. The Maroon is the most visible symbol of this gesture of cultural dédoublement.

According to Richard Price, runaway African slaves managed to maintain their autonomy from the dominant culture by both mastering European modes of resistance and improvising American ones; in Maroon societies, ideological commitment to "things African" was formulated through "nascent but already powerful plantation-forged Afro-American cultures." 52 Many Caribbean writers have hence adopted maroonage as a metaphor for cultural production in foreign lands and, specifically, for writing in a colonial situation. Cultural maroonage, argues Depestre, is a subversive strategy adopted by slaves "to restructure their disembodied components of their historical identity in the unfamiliar world," to find "the new truth of their lives," or to "rework their shredded African traditions." 53 Like the slaves fleeing into the hills to establish autonomy, the modern Caribbean writer seeks to rework European forms and genres to rename the experience of the "other" American.

But Depestre's claim, in another context, that maroonage is a form of "escape from western culture," needs to be qualified in one important respect: this escape has never been complete. ${ }^{54}$ Indeed, as Richard Price observes of the original Maroons, the survival of autonomous African communities in the New World always depended on a paradoxical relationship with the plantation structure; while Maroons were, "from one perspective, the antithesis of all that slavery stood for, they were at the same time everywhere an embarrassing visible

52. "Introduction: Maroons and Their Communities," in Maroon Societies: Rebel Communities in the Americas, ed. Richard Price (New York: Anchor, 1973), p. 28. See also Franklin W. Knight, The Caribbean: Genesis of a Fragmented Nationalism (New York: Oxford University Press, 1978), pp. 69-73; and Mavis C. Campbell, The Maroons of Jamaica 1655-1796 (Trenton, N.J.: Africa World Press, 1990). The most comprehensive examination of the theme of resistance in Caribbean literature is Selwyn Cudjoe's Resistance and Caribbean Literature (Athens: Ohio University Press, 1980).

53. René Depestre, "Hello and Goodbye to Negritude," in Africa in Latin America: Essays on History, Culture, and Socialization, ed. Manuel Moreno Fraginals, trans. Leonor Blum (New York: Holmes and Meier, 1984), pp. 258-59.

54. René Depestre, "Problems of Identity for the Black in the Caribbean," in Hearne, Carifesta Forum, p. 62. 
part of these systems." 55 Maroonage as Houston Baker has argued, evinces a discourse that adopts skills and knowledge borrowed from the "master culture" to represent "a community of national interests set in direct opposition to the general economic, political, and theological tenets of a racist land." 56

Nowhere is maroonage as a gesture of discursive Caribbean modernism as evident as in Césaire's Cahier, a text in which linguistic resistance is underwritten by a parasitic relationship to the language community the poet opposes. Simply put, the Cahier, one of the most radical gestures in Caribbean literature, is also indebted to, possibly haunted by, the European modernist models it adopts to strike at the foundations of Eurocentrism. As A. James Arnold has noted in his comprehensive study of negritude and modernism, to attack the world view that engendered slavery and colonialism, Césaire was "constrained by his education to forge weapons out of the adversary's own arsenal." 57 Arnold proceeds to formulate Césaire's agonized relationship to the European tradition in terms that explain the modernist bent in Caribbean writing: "As a black Martinican, Césaire stood inside and outside the culture of France and of Europe. His struggle was to prove especially painful and its outcome especially problematic because in attacking modern Europe he was at the same time attacking a part of himself." 58 As Caliban, Césaire would use the ecumenical language of high modernism to amplify his call for "decolonization within the bounds of the dominant cultures," but he was painfully imprisoned in the French language. ${ }^{59}$

Now, to the extent that it seeks to disperse the already written discourse of colonialism, the maroonage gesture Caribbean writers associate with Caliban is commensurate with that act of dispersal which, according to Michel Foucault, realizes a new discursive formation by opening different possibilities of "reanimating already existing themes, of rousing opposed strategies, of giving way to irreconcilable interests, of making it possible, with a particular set of concepts, to

55. Richard Price, "Introduction: Maroons and Their Communities," in Maroon Societies, p. 21.

56. Baker, p. 77.

57. A. James Arnold, Modernism and Negritude: The Poetry and Poetics of Aimé Césaire (Cambridge: Harvard University Press, 1981), p. 70.

58. Arnold, p. 70.

59. Césaire, Discourse, pp. 67, 68. 
play different games." 60 Within this formulation, a new Caribbean discourse is generated by the colonized writer's guerrilla attack on the dominant culture through what Césaire would call a "surrealistic" onslaught. Reflecting on his linguistic strategies in the Cahier, Césaire notes that the power of his poem, especially its ability to break through the silence imposed on the Caribbean peoples by the colonizer through the colonial language, is largely due to his use of poetic maneuvers to deconstruct the "already written" aspects of colonial discourse, and to his use of surrealistic techniques as weapons "to explode the French language" and ignite a process of disalienation. 61

Patrick Taylor's conclusion that Césaire's poem is bound and possibly disabled by "its own starting point" - the poet's assimilationist tendencies and his implicit acceptance of "the white myth" - is quite valid, but this hindrance should not draw attention away from the linguistic radicalism embedded in the structure of the Cahier. ${ }^{62}$ Whatever its limitations, what makes Césaire's poem so remarkable in the discourse of decolonization is its initial conceptualization as a fragment that, nevertheless, exists as the preliminary toward a whole: the poet falls back on the "discourse of deracination" borrowed from European modernism to explode the colonizer's claim of an integrated Caribbean culture (i.e., one integrated to the empire). The instruments of displacement are valorized; psychological and cultural dysfunction is foregrounded as an object that blocks consciousness and the self's access to its true nature; the dispersal of the dominant figures of colonial discourse, and the celebration of the negative, realize the poetic act. 63

We can better appreciate the power and value Césaire bestows on displacement if we recall that the poet's point of entry into the Cahier (his entry into the French language as it were) is itself an absence, a twilight zone- "At the end of the wee hours." This absence, however, is the incentive to new meanings: in the "inert town" of the poet's

6o. Michel Foucault, The Archeology of Knowledge and the Discourse on Language, trans. A. M. Sheridan Smith (New York: Pantheon, 1982), pp. 36-37.

61. Césaire says he was ready to accept surrealism because it was "a weapon that exploded the French language. It shook up absolutely everything. This was very important because the traditional forms-burdensome, overused forms were crushing me." See Discourse, p. 67.

62. Taylor, p. 181 .

63. Ronnie Scharfman, "Repetition and Absence: The Discourse of Deracination in Aimé Césaire's 'Nocturne d'une nostalgie,' " The French Review 56 (March 1983), 572. See also Serge Gavronsky, "Aimé Césaire and the Language of Politics," French Review 56 (December 1982), 273-80; and Joan Dayan, "The Figure of Negation: Some Thoughts of a Landscape by Césaire," The French Review 56 (February 1983), 411-21. 
birth, the speaker is confronted by a throng "detoured from its true cry," suggesting that the poetic utterance cannot be constructed on perceptual figures (p. 35). In the tradition of his European modernist counterparts, as discussed by Alan Wilde, Césaire falls back on language not "as a means of discovering or evoking some final and ultimate 'Truth,' but as a way of releasing the self and thereby making the phenomenal world . . . the scene of purposeful action." 64 The poetic voice is painful and fragmented, however, and the speaker is forced to enunciate in the ill-defined zone of deracination. Because Césaire can only create meanings by writing about silence, absence, death, and denial, his discourse effectively exists in a space of double inscription: it traces the same lines along which the colonizer has structured the black subject, but this gesture is a form of subversionit has assumed opposite and reversed ideological value.

What is important for us to note, however, is that Césaire's notion of displacement is not the Derridian sojourn in the wilderness of uncertainty. While Derrida argues that displacement does not "overturn" the authority of the old truth, and does not, as a result, take place as an event ("It does not occupy a simple place. It does not take place in writing"65), Césaire posits the dislocation of old meanings as the prelude to the creation of new ones in writing. Linguistic displacement is imperative to the poetics of decolonization because, by tracing the historical and discursive origins of the subject's dislocation, the poet transcends his or her limitations through writing. What Joan Dayan calls Césaire's language of copia is evidence of his ability (or desire) to turn displacement into a performative event that will enable him to "find a voice amid the remnants of an idiom springing from historical realities and ways of cognizance alien to his own." 66 In the twilight zone of colonialism, the displaced subject returns and embraces "its land without a stale, / these paths without memory, these winds without memory, these / winds without a tablet," but instead of becoming overwhelmed by his alienation on the site of colonialism, he uses his absences to launch his "Full voice, ample voice" as "our wealth, our spear" (p. 49). And thus in New World modernism, the mastery of form goes hand in hand with its deformation; out of silence

64. Wilde, p. 99.

65. Jacques Derrida, Dissemination, trans. Barbara Johnson (Chicago: University of Chicago Press, 1981), p. 193.

66. Dayan, p. 415 
arises, like the phoenix, a new voice. This modern voice proposes a different reading of what Wilson Harris calls "the office of language."67

\section{Reading Caribbean Modernism}

But the greatest challenge facing any critic of Caribbean literature is one of epistemology and historical periodization. For if Caribbean modernism implies an unceasing process of revisionism, as Wilson Harris has constantly insisted, it also presents us with innumerable difficulties of definition and perspective. ${ }^{68}$ As a Caribbean modernist who wants to appropriate the revolutionary linguistic strain in the literary avant-garde while renouncing the imperialism that underwrites the "discovery," Harris adopts a geographic metaphor to help him situate his aesthetic. Modernity, he argues, is an escarpment dividing the moment of conquest and loss for "the ancient American civilizations" from the temporal movements through which Europe renews and empowers itself: "This escarpment seen from another angle possesses the features of a watershed, main or subsidiary, depending again on how one looks at it."69 The position of the writer on this escarpment is possibly the most urgent issue in the quest for a Caribbean hermeneutics.

Thus if George Lamming seems intent on transforming the original error of "discovery" into an American gnosis, it is because he realizes, as do many of his contemporaries, that what is at stake in the representation of the islands is not the discovery of an original model or presence, but the projection of new desires and ideologies. The value of Columbus's adventure, notes Lamming, lies in its ironic results, which show that the original purpose of a journey "may sometimes have nothing to do with the results that attend upon it." 70 In simple hermeneutical terms, modernity in the Caribbean has always manifested itself in contradictory and often antagonistic tendencies, which need to be stressed because they explain many of the shifts in Carib-

67. Quoted in Sandra E. Drake, Wilson Harris and the Modern Tradition (Westport, Conn.: Greenwood, 1986), p. 10. My reflections on a particular kind of Caribbean modernism are indebted to Drake's discussion of the ways in which "non-Western paradigms also constitute part of the Modernist tradition" (p. xii).

68. See Harris's interview with Slemon, p. 48.

69. Wilson Harris, Tradition, the Writer, and Society (London: New Beacon Books, 1973), pp. 30-31.

70. Lamming, The Pleasures of Exile, p. 36. 
bean discourse in the twentieth century. Clearly, any periodization of Caribbean literature will always remain suspect and possibly undesirable; a "schematic history," censures J. Michael Dash, may gain in "shapeliness but lose a sense of the diversity and contradictions of the events it attempts to explain."71 Dash proceeds to provide an alternative recuperation of Caribbean literary history-one transcending "the hierarchical, the fixed, the linear" - which I have adopted as my model in selecting texts and periods of study: "In tracing [the writer's] concern with the expressiveness and redeeming force of language, we may well see the Caribbean writer as a modern Quixote, relying on his imagination in order to confer meaning on an elusive and complex reality."72

Each of the chapters in this book focuses on what I consider to be significant points in the imaginary journey of Caribbean writers as they struggle to explicate or confer meanings on the complex realities of the region. In Chapter 1, for example, my emphasis is on themes of displacement and exile in C. L. R. James's Beyond a Boundary and George Lamming's The Pleasures of Exile. I am well aware of a certain uneasiness among many Caribbean writers and intellectuals as to any foregrounding of fragmentation and exile in Caribbean discourse, but my assumption here is that any meaningful account of Caribbean literature cannot ignore the angst that has generated some of the most powerful texts on the colonial situation. It is not by accident that such narratives (notable examples include Edgar Mittelholzer's A Morning at the Office and V. S. Naipaul's A House for Mr. Biswas) are concerned with the insecure position of the colonial subject in an emerging social order and his or her attempt to develop a meaningful relationship with the alienating historical context of colonialism and of the dominant European culture. As Selwyn Cudjoe has observed in his study of Naipaul's works, the colonial subject writes to externalize the past in order to examine it. "Once having externalized the past, he can bear the pain caused by such an examination."73 Thus even a narrative on the failure of the colonial subject to find a site of identity in the colonized landscape still affords us insight into the dialectic that defines this subject- "his alienation, the immanent nature of his social

71. J. Michael Dash, "The World and the Word: French Caribbean Writing in the Twentieth Century," Callaloo 11 (Winter 1988), 113.

72. Dash, "The World and the Word," p. 115.

73. Selwyn R. Cudjoe, V. S. Naipaul: A Materialist Reading (Amherst: University of Massachusetts Press, 1988), p. 61. 
existence, the particularity of his social being, and the historical dimension of his existence." 74

Rather than denying the historicity of the Caribbean experience, a concern with displacement and exile becomes the first major attempt by Caribbean writers to engage the colonial condition on their own terms. Furthermore, as a historical condition and literary code, exile is not a subjective quest by the Caribbean avant-garde to escape their fixed and fetishized places in the colonial culture. On the contrary, as Jean D'Costa and Barbara Lalla observe in Voices in Exile (an exemplary study of some of the earliest texts of Caribbean expression), "The experience of exile is central to Jamaican history and to the making of language in a Jamaica which spelled banishment for most of its people." 75 The centrality of exile is further underscored by Lamming, who insists that "to be colonial is to be a man in a certain relation; and this relation is an example of exile." 76

Furthermore, there is a vital epistemological consequence to the condition of exile: it forces an earlier generation of Caribbean writers (especially in the 1940s and 1950s) to an irreversible cognizance of their cultural schizophrenia; in turn, this awareness of division comes with what Walcott has aptly called "a gradual sense of a loss of innocence about history."77 This loss of innocence is the central paradigm in James's Beyond a Boundary. As I argue in the next chapter, in his seminal discourse on cricket - as both metaphor and metonym for the colonial situation, its culture and its institutions-James was able not only to reverse entrenched notions about play, class, color, and nationalism, but also to mediate the two modes of desire (the bourgeois and the popular) which defined the colonial relationship. Moreover, as Sylvia Wynter has succinctly noted, the pattern of Beyond a Boundary, "working out the logic of its own motifs, uncovers 'large areas of human existence,' as James points out, that his 'history, economics, politics' had left unaccounted for. Here it reveals that a separation, a gap appeared between the mode of popular desire, i.e., what the masses wanted to live by and what the 'ruling elements' wanted them to live by."78 This gap of desire has important formal and discursive implica-

74. Cudjoe, V. S. Naipaul, p. 73.

75. "Introduction," Voices in Exile: Jamaican Texts of the 18th and 19th Century, ed. Jean D'Costa and Barbara Lalla (Tuscaloosa: University of Alabama Press, 1989), p. 1.

76. The Pleasures of Exile, p. 156.

77. Charles H. Rowell, "An Interview with Derek Walcott," Callaloo 11 (Winter 1988), 81.

78. Sylvia Wynter, "In Quest of Matthew Bondman: Some Cultural Notes on the Jamesian Journey," in C. L. R. James: His Life and Work, ed. Paul Buhle (London: Allison and Busby, 1986), p. 131. 
tions, which I discuss in my analysis of the discourse of decolonization in the works of James and Lamming.

In Chapter 2, I discuss narrative strategies in Lamming's early fiction as one way of examining some of the most important issues confronting Caribbean culture in the age of decolonization, more specifically, the problem of language and representation. Beginning with the important nationalist uprisings of the 1930s (In the Castle of My Skin), moving us through the immigration of many West Indians to the metropolis in the 1950s (The Emigrants), and culminating with the apotheosis of decolonization as the affirmation of national culture (Season of Adventure), Lamming's early novels represent the drama of liberation and its problematic issues while tracing the cycles of contemporary Caribbean history. Lamming is, by his own confession, a very thematic writer, and the central themes of his novels have been discussed definitively in some excellent critical studies. Given the existence of substantial critical literature on Lamming and the politics and poetics of the colonial situation, my concern in this chapter is to shift emphasis from the overt rhetoric of Lamming's novels to more specific questions about language-as it relates to representation and identity -and the value and function of the act of narration itself. I will try to show that Lamming's novels are remarkable for their self-conscious subversion of traditional conventions of realism and their rejection of coherence in narrative language.

This subversive strain might be explained by Lamming's historical proximity to high modernism, but it is more probably a result of his acute understanding of the problems of language in a colonial situation. In the colonial encounter, Lamming once told George Kent,

Caliban received not just words, but language as symbolic interpretation, as instrument of exploring consciousness. Once he had accepted language as such, the future of his development, however independent it was, would always be in some way inextricably tied up with that pioneering aspect of Prospero. Caliban at some stage would have to find a way of breaking that contact, which got sealed by language, in order to structure some alternative reality for himself. ${ }^{79}$

My close reading of In the Castle of My Skin shows how the colonized subjects' striving to use language as an instrument of consciousness always seems to reach a dead end, forcing them to restructure and 


\section{INTRODUCTION}

reinvent their language in order to have a handle on a colonial reality and history previously foreclosed from them. Moreover, narrative, and the act of narration, have immense powers to counter the colonial vision; against the stasis of imperialism, narrative introduces the disruptive power of temporality. My theoretical premise here is best articulated by Edward Said in Orientalism:

Narrative asserts the power of men to be born, develop, and die, the tendency of institutions and actualities to change, the likelihood that modernity and contemporaneity will finally overtake "classical" civilizations; above all, it asserts that the domination of reality by vision is no more than a will to power, a will to truth and interpretation, and not an objective condition of history. Narrative, in short, introduces an opposing point of view, perspective, consciousness to the unitary web of vision; it violates the serene Apollonian fictions asserted by vision. ${ }^{80}$

The narrative deconstruction of the colonial vision which dominates Caribbean literature is often seen as a prelude to a unified national consciousness in each of the islands. A central concern in the Trinidad novels of Samuel Selvon, which I discuss in Chapter 3, is the need to imagine a national community in which the different cultures in the island can be harmonized into a modern nation, a community of language and shared consciousness. Selvon's ideological and narrative concerns revolve around the forms in which East Indians in Trinidad can overcome the mythologies surrounding their cultures, mythologies that have often come between them and the black population of the island. Narrative provides Selvon with an apparatus for imagining and realizing the dream of creolization through the evocation of a calypso aesthetic. Here the calypso functions as a metaphor of an emerging, or imagined, nationhood. As Albert Gomes once observed in regard to the period covered by Selvon in A Brighter Sun, "The calypso singer has begun to announce in his songs that our ethnic 'potpourrie' is a reality, and that its many pots have begun to pour one into the other. The welding of our polyglot community is taking place before our eyes in the 'tents' and the weddings of our culture are being celebrated right there." 81 The desire for the polyglot community-and the problems that block its realization-function as a central paradigm in Selvon's novels.

80. Said, ep. 240.

81. Quoted by F. Gordon Rohlehr, "TheFolk in Caribbean Literature," in Critical Perspectives on Sam Selvon, ed. Susheila Nasta (Washington, D.C.: Three Continents Press, 1988), p. 36. 
As products of the colonial situation, the writers examined here are all preoccupied with larger problems of history and historiography. But one problem that permeates the Caribbean experience and the discourse on decolonization is the repression and distortion of a Caribbean version of global events. Glissant tells the story of the Guadaloupean patriot Colonel Delgrès, who in 1802 blew up himself and three hundred of his compatriots rather than give in to the edict that reintroduced slavery in the French colonies in the region. But when this event was written into the March 1848 proclamation abolishing slavery, the French government "asserted that Guadaloupeans had themselves demanded the reimposition of slavery in $1802 . "{ }^{\prime \prime} 82$ Consequently, in order to "repossess their historical spaces," argues Glissant, Caribbean countries have to find a detour around the ideological blockades put up by European history.

Although my selection of Alejo Carpentier's El siglo de las luces (Explosion in a Cathedral) as the focus of Chapter 4 may appear unusual in a study devoted primarily to Anglophone Caribbean novels, the text affords me an opportunity to discuss the ways Caribbean narratives penetrate and unsettle the discourse of history itself. Set during the period of the French Revolution and the Enlightenment, this novel shows how the "other" America functioned to call the philosophy of European history into question. As Roberto Gonzalez Echevarria has asserted, this novel "centers on that moment when the various versions of history are pitted against each other in an attempt to reach a master version." 83 However, the European drive for a master version of history is haunted and ultimately reverted by the black slaves who articulate their history using carnivalesque strategies that parody the Western desire for rationalization. In this regard, I concur with Gonzalez Echevarria's assertion that Carpentier's novel is important to the Caribbean literary tradition "because of the way in which it delves into the very core of the dilemma of what constitutes American history and how to narrate it." 84

A similar preoccupation with the forms of black history in the New World is central to the narrative strategies Paule Marshall adopts in the novels I examine in Chapter 5. In The Chosen Place, the Timeless People, in

82. Glissant, p. 62.

83. Roberto Gonzalez Echevarria, "Socrates among the Weeds: Blacks and History in Carpentier's Explosion in a Cathedral," in Voices from Under: Black Narrative in Latin America and the Caribbean, ed. William Luis (Westport, Conn.: Greenwood, 1984), p. 37.

84. "Socrates among the Weeds," p. 37. 


\section{INTRODUCTION}

particular, the drive for modernization in the postcolonial period is of ten a mask of power adorning a new native ruling class, which has appropriated the ideological configurations of the colonizing structures to justify its class domination. Marshall's critique of a nationalist ideology that betrays its own aspirations and logic is already prefigured by Lamming, who, at the end of In the Castle of My Skin, details the rise to power of a native ruling class (symbolized by Slime, the school teacher). In aligning itself with the planters, this ruling class negates the original dream of nationalism and independence as the apotheosis of decolonization, thus exposing the modern state as what Jean Franco aptly calls "a kind of illusionist which needs the past only as a lament and whose miracle is the economic miracle of dependency." 85

In this context, as Frantz Fanon notes in his famous critique of nationalism, "National consciousness, instead of being the all-embracing crystallization of the innermost hopes of the whole people, instead of being the immediate and most obvious result of the mobilization of the people, will be in any case only an empty shell, a crude and fragile travesty of what it might have been." 86 Many novels produced by Caribbean writers after independence are variations on Fanon's critique: from Lamming's later works (especially Season of Adventure) to more recent novels such as Earl Lovelace's The Wine of Astonishment and Michael Thelwell's The Harder They Come, the novel provides a framework for questioning previous assumptions about culture and identity, political independence, ethnicity, class, and gender. These are the kinds of "Third World" novels which, in Jean Franco's words, "offer a motley space in which different historical developments and different cultures overlap. What they enact is the unfinished and impossible project of the modernizing state." 87

At the same time, many Caribbean writers believe that one reason national discourse has been found wanting in the postcolonial period is that it sustains its own forms of exclusion, especially in relation to questions of class, gender, and sexuality. A significant critique of nationalist discourse as a system of patriarchal power emerges in Caribbean literature as early as 1960 in Lamming's Season of Adventure,

85. Jean Franco, "The Nation as Imagined Community," in The New Historicism, ed. H. Aram Veeser (New York: Routledge, 1989), p. 206.

86. Frantz Fanon, The Wretched of the Earth, trans. Constance Farrington (New York: Grove Press, 1968), p. 148.

87. Franco, "The Nation," p. 205. 
where the failure and collapse of an independent Caribbean nation are attributed to the exclusion of the poor and women from power. In the character of Fola, who represents the feminine principle in Caribbean culture, Lamming seeks regeneration in the power of women. Although she is an educated member of the Caribbean middle class, Fola is, like the peasantry in the island, also marginalized in relation to the patriarchal institutions of the postcolonial state. Shared exclusion gives her the license to identify with popular culture, however; by undergoing the vodun Ceremony of Souls she positions herself against "the civilised honour of the whole republic," an act of abnegation which brings her into an encounter "with her forgotten self." 88 As Sandra Pouchet Paquet concludes in her reading of the novel, Fola's quest for her unknown father "is ultimately the search for an alternative tradition that accommodates the African and peasant roots of the San Cristobal community, long obscured by colonial history." 89

Lamming's introduction of the gender factor into the discourse on national identity sets the stage for contemporary Caribbean women writers such as Merle Hodge, Zee Edgell, and Michelle Cliff, whose works I examine in the last two chapters of this book. While I would hesitate to argue that the three women writers I discuss hold any magic keys to the postcolonial phenomenon in Caribbean literature, a "feminist" challenge to previous assumptions about modernism and nationalism is imperative for an understanding of the major debates taking place in the region today. For one thing, the problem of national identity and modernity in the Third World has too of ten been limited by its failure to confront its gender bias. As Franco observes in another context, the modern allegory of the nation is presented primarily as centering on the crisis of male identity; in the process women function as "the territory over which the quest for (male) national identity passed, or ... the space of loss." 90 Thus in discussing her politics and poetics, Olive Senior, a leading Jamaican writer, observes that while ideological issues may not have changed significantly in Caribbean literature since independence, there has been a reconfiguration of the form in which such issues are explored: "The fact that Caribbean women writers have now come to the fore is opening up to us a

88. George Lamming, Season of Adventure (London: Allison and Busby, 1979), pp. 68 and 50.

89. Sandra Pouchet Paquet, The Novels of George Lamming (London: Heinemann, 1982), p. 70.

90. Jean Franco, Plotting Women: Gender and Representation in Mexico (London: Verso, 1989), p. 131. 


\section{INTRODUCTION}

completely new approach to the topic of the Caribbean mother-one of our great literary preoccupations-and of our relationship with that mother. It is also, I believe, personalizing the socio-political issues."91

And while I am aware that all generalizations are dangerous because they are often blind to the exception to the rule, Caribbean women writers seem more amenable to formal experimentation than their male counterparts. Michael Thelwell's The Harder They Come negotiates the same ideological terrain as Cliff's Abeng and Erna Brodber's Jane and Louisa Will Soon Come Home, but the three texts are motivated by different assumptions about literary form. Thelwell advocates "realism" and is contemptuous of modernist forms that emphasize fragmentation instead of coherence; he argues that the modernist novel "is quite useless for the projection of political and moral vision or statement. Its tone is parodic and its impulses contemptuous-both of the reader and of observable reality." 92 Cliff and Brodber, on the other hand, adopt fragmentation and parody as key elements of their narrative strategies; by breaking up and parodying the master code, they seek reconnection with their historical reality. In both cases, however, what is important for my study is the extent to which a new generation of Caribbean women writers is revising the project of their male precursors who had, in turn, revised and dispersed the colonial canon. My hope is that both male and female revisionings of colonial discourse and the re-presentation of previously excluded Caribbean selves will also force us to revise our notions of modernism and its relationship to colonialism and to so-called postcolonialism.

91. Charles H. Rowell, "An Interview with Olive Senior," Callaloo 11 (Summer 1988), 485. 92. Thelwell, p. 225. 